\title{
Proliferation of human mammary cancer cells exposed to 27-hydroxycholesterol
}

\author{
PAMELA CRUZ ${ }^{1 *}$, CRISTIAN TORRES $^{2 *}$, MARÍA EUGENIA RAMÍREZ ${ }^{1 *}$, MARÍA JOSÉ EPUÑ̃́N ${ }^{1}$, \\ LUIS EMILIO VALLADARES ${ }^{1}$ and WALTER DANIEL SIERRALTA ${ }^{1}$ \\ ${ }^{1}$ Laboratorio de Nutrición y Regulación Metabólica, INTA-Universidad de Chile, Santiago 7830489; \\ ${ }^{2}$ Laboratorio de Medicina Experimental, Escuela de Medicina Veterinaria, Universidad Andrés Bello, Santiago 8370251, Chile
}

Received February 10, 2010; Accepted March 22, 2010

DOI: $10.3892 /$ etm_00000084

\begin{abstract}
The aim of the present study was to identify the possible mechanisms by which certain estradiol receptor (ER)-positive mammary tumor cells remain resistant to treatment with anti-estrogens or inhibitors of local estradiol $\left(\mathrm{E}_{2}\right)$ production. To this end, we compared the proliferative effects on mammary cancer cells of the novel selective ER modulator 27-hydroxycholesterol (27OHC) to those of $\mathrm{E}_{2}$, and evaluated their inhibition by ICI 182,780 (ICI). Analysis of the effects on the cell cycle of $27 \mathrm{OHC}$ and $\mathrm{E}_{2}$ in the absence or presence of ICI was conducted. In ER-positive mammary tumor cells, we detected the blocking of $27 \mathrm{OHC}$ proliferationstimulatory activity by simvastatin, as well as the inhibition of $\mathrm{E}_{2}$-stimulated proliferation by an $\alpha$-fetoprotein-derived cyclic nonapeptide. The effects reported herein may be extrapolated to infiltrating mammary cancer, where the activity of local macrophages may stimulate tumor growth. We suggest that increased breast cancer growth in obese patients may be related to increased $27 \mathrm{OHC}$ circulatory levels.
\end{abstract}

\section{Introduction}

Breast cancer is the leading cause of morbidity and mortality in women worldwide. Some types of breast cancer are under estrogen control (1). By associating with nuclear estrogen receptors (ERs), estradiol and selective modulators of estrogen receptors (SMER) affect the growth of mammary gland neoplasias through the regulation of genomic processes (2). In addition, estradiol and certain SMER associate with cognate receptors in the cell membrane or the cytoplasm, and control non-genomic effects $(3,4)$.

Correspondence to: Dr Walter D. Sierralta, Laboratorio de Nutrición y Regulación Metabólica, INTA-Universidad de Chile, Avda. Macul 5540, Santiago 7830489, Chile

E-mail:wsierra@inta.cl

Key words: MCF7 cells, proliferation, estradiol, ICI 182,780, 27-hydroxycholesterol, simvastatin, epidermal growth factor receptor-2
The concentration of estrogens in breast tissue depends on the uptake from circulation and local production; the latter seems to be precisely controlled by the activity of a variety of nuclear receptors (5). Local levels of estradiol maintain the operation of numerous biological functions in normal and neoplasic breast tissue. Of particular importance among these is cell proliferation. For this reason, the blockade of ER activation by anti-estrogens and the reduction in estrogen availability through the use of inhibitors of aromatase and other enzymes involved in the local synthesis of the steroid are important therapeutic strategies used to hinder the progress of ER-positive mammary cancer (6). However, not all ER-positive breast cancers respond to these treatments, and many tumors eventually acquire resistance during therapy, probably due to the sustained functioning of ER-related pathways (7). Therefore, a better understanding of the mechanisms that maintain the activation of the ER signaling pathways in cancer cell progression is required for the development of new therapeutic approaches.

The association of a particular SMER to an ER has an effect on the overall conformation of the protein. The specific conformation of the complex determines the differential recruitment of co-activators or co-repressors as well as the biochemical and physiological activities to be expressed (7-9). Serum and the fluids bathing cells, organs and tissues contain compounds with the potential to imitate estrogens. In this regard, it has been reported that 27-hydroxycholesterol (27OHC), an oxysterol produced by the intramitochondrial oxidation of cholesterol, may act as a non-conventional SMER in estradiol-target cells $(10,11)$. In normal subjects, plasma $27 \mathrm{OHC}$ concentration is in the same order of magnitude as the dissociation constant of the complex between ER and $27 \mathrm{OHC}$, thus assuring their stable association. In endothelial cells, 27OHC functions as an estradiol antagonist, and some authors assume that its increased release by atheroma cells is responsible for damage to vascular endothelial and muscular cells in the vicinity of the atherosclerotic plaques $(10,11)$. However, in ER-positive mammary tumor cells $27 \mathrm{OHC}$ works as an estradiol agonist, promoting cell proliferation (11).

In the present study, we compared the activity of $27 \mathrm{OHC}$ and estradiol on the proliferation of mammary cancer cells in culture, and determined their inhibition by the specific antagonist ICI 182,780. Analysis of the effects of $27 \mathrm{OHC}$ 
on the cell cycle was also conducted. Additionally, we evaluated the effects of simvastatin, a specific inhibitor of 3-hydroxy-3-methyl-glutaryl-CoA reductase (HMGR), on the proliferative activity of $27 \mathrm{OHC}$. Lastly, we studied the effects of an $\alpha$-fetoprotein (AFP)-derived cyclopeptide on tumor cell proliferation under estradiol and $27 \mathrm{OHC}$ stimulation.

\section{Materials and methods}

Tissue culture materials were obtained from NalgeNunc (Rochester, NY, USA). 27-hydroxycholesterol (C6570-000) was purchased from Steraloids Inc. (Newport, RI, USA). Dulbecco's phosphate buffered saline (DPBS) was from Gibco-Invitrogen Corp. (Carlsbad, CA, USA). Pure antiestrogen ICI 182,780 (ICI) was purchased from Tocris Bioscience (Ellisville, MO, USA). The majority of the other reagents were purchased from Sigma-Aldrich Inc. (St. Louis, MO, USA).

The AFP-derived nonapeptide [AFPep, cyclo(EKTOVNOGN), where $\mathrm{O}$ is hydroxyproline] was generously supplied by Professor H.J. Jacobson and colleages of the Albany Medical College, NY, USA.

Rabbit anti-c-erbB2 polyclonal antibody (ab2428) was obtained from Abcam plc (Cambridge, UK). Alexa Fluor 488 conjugated goat anti-rabbit IgG (A11008) was purchased from Molecular Probes-Invitrogen Corp. (Carlsbad, CA, USA).

$\mathrm{E}_{2}$-sensitive MCF7 epithelial cells from human metastatic breast cancer tissue (HTB 22; ATCC, USA) were cultured in DMEM/F12 containing $10 \%$ fetal bovine serum, $1 \mathrm{mM}$ sodium pyruvate, $2 \mathrm{mM}$ L-glutamine, $100 \mathrm{U} / \mathrm{ml}$ penicillin and $100 \mu \mathrm{g} / \mathrm{ml}$ streptomycin. In the proliferation studies, the cells were transferred $24 \mathrm{~h}$ after seeding to DMEM/F12 containing ITS (insulin, transferrin and selenium), 1\% charcoal/dextrantwice-treated serum (CDTS), 3\% hydroxyethylated starch (HAES), $50 \mathrm{U} / \mathrm{ml}$ penicillin and $50 \mu \mathrm{g} / \mathrm{ml}$ streptomycin. The non-tumorigenic $\mathrm{E}_{2}$-insensitive epithelial cell line MCF10 (CRL-10317; ATCC, USA) was used for control studies, and was cultured under the same conditions as MCF7. In each of the experiments, the cells were incubated at $37^{\circ} \mathrm{C}$ in a humidified incubator under a $5 \% \mathrm{CO}_{2}$ atmosphere.

Proliferation studies. As indicated above, MCF7 or MCF10 $\left(\sim 20,000\right.$ cells $\left./ \mathrm{cm}^{2}\right)$, were seeded and incubated for $24 \mathrm{~h}$ to allow attachment, then non-adherent cells and media were removed. The remaining cells were washed and further incubated for various periods with low-serum culture medium containing either $2 \mathrm{nM} \mathrm{E}_{2}$ or different concentrations of $27 \mathrm{OHC}$ or cholesterol, in the absence or presence of either $2 \mu \mathrm{g} / \mathrm{ml}$ AFPep, $1 \mu \mathrm{M}$ simvastatin or $100 \mathrm{nM}$ ICI. Upon completion of the incubation period, cells were washed with DPBS, detached (0.25\% trypsin in $0.2 \mathrm{mM}$ EDTA), resuspended in DPBS, counted and assessed for viability using the trypan blue assay. Each experiment was performed at least three times in triplicate.

Immunofluorescence studies. Cells exposed to different experimental conditions were grown on a sterile coverglass and then fixed (absolute methanol at $-20^{\circ} \mathrm{C}$ ), rinsed with DPBS and blocked for 30 min with $2 \%$ BSA in DPBS. Subsequently, the samples were incubated with the primary antibodies for $1 \mathrm{~h}$ at room temperature. After extensive washes in DPBS

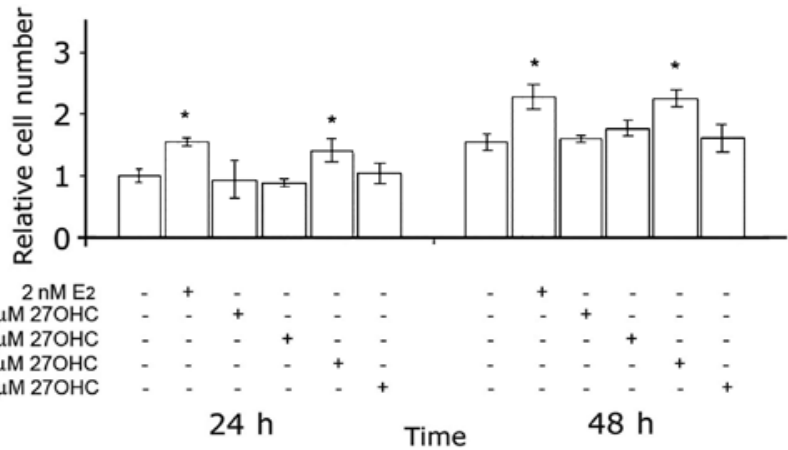

Figure 1. Effect of estradiol and 27OHC on the proliferation of MCF7 cells in culture. MCF7 cells were incubated for the indicated times in medium containing $1 \%$ charcoal-treated serum and $3 \%$ HAES in the absence or presence of $2 \mathrm{nM} \mathrm{E}_{2}$ or with increasing concentrations of $27 \mathrm{OHC}$. The proliferation rate was expressed as the relative cell number calculated in relation to the number of control cells at $24 \mathrm{~h}$ after seeding, which was set to 1 . Values are the mean $\pm \mathrm{SD}$ of 3 individual experiments performed in triplicate. ${ }^{*} \mathrm{P}<0.05$ compared to non-stimulated control cells.

containing $2 \% \mathrm{BSA}$, the samples were incubated with the appropriate secondary antibody for $1 \mathrm{~h}$ and washed. Nuclei were counterstained with 7-aminoactinomycin D (BD Pharmingen, San Diego, CA, USA). After a final washing, the samples were mounted with Biomeda Gel/Mount (Foster City, CA, USA) and inspected with a Zeiss Axiophot epifluorescence microscope fitted with a color CCD camera (Kappa $\mathrm{GmbH}$, Goettingen, Germany). In each experiment, the images were obtained under fixed settings of illumination, exposure time and camera gain.

Cell cycle analysis. Approximately $8 \times 10^{5} \mathrm{MCF} 7$ cells/well were seeded in 6-well plates and treated as described for the respective experiments. Analysis was performed using the FITC BrdU Flow kit (BD Pharmingen) following the manufacturer's instructions. After the different stimuli, cells were incubated for $240 \mathrm{~min}$ with $10 \mu \mathrm{M}$ BrdU and detached using trypsin-EDTA before fixation in BD Cytofix/Cytoperm buffer. After DNase treatment to obtain a better exposure of the epitopes, the incorporated BrdU was detected with the FIT-conjugated anti-BrdU-antibody. DNA was counterstained with 7-aminoactinomycin D for $30 \mathrm{~min}$, then the samples were finally resuspended in staining buffer and analyzed within $1 \mathrm{~h}$. Before any treatment, the MCF7 cells were synchronized by $24 \mathrm{~h}$ serum deprivation, and then incubated for $24-48 \mathrm{~h}$ with vehicle, $2 \mathrm{nM} \mathrm{E} 2$ or different concentrations of $27 \mathrm{OHC}$ in the absence or presence of $100 \mathrm{nM}$ ICI. Flow analysis was performed with a BD-FACSCalibur cytometer.

Statistical analyses. The student's t-test was used to evaluate differences between the samples and their respective controls. $\mathrm{P}<0.05$ was considered significant. Data were analyzed using Statistica version 6 for Windows (Statsoft Inc., USA).

\section{Results}

The effects of 27OHC on the proliferation of MCF7 cells in media containing low levels of serum were first analyzed. The results are depicted in Fig. 1, and indicate that $27 \mathrm{OHC}$ stimulated mammary tumor cell proliferation. The maximal 


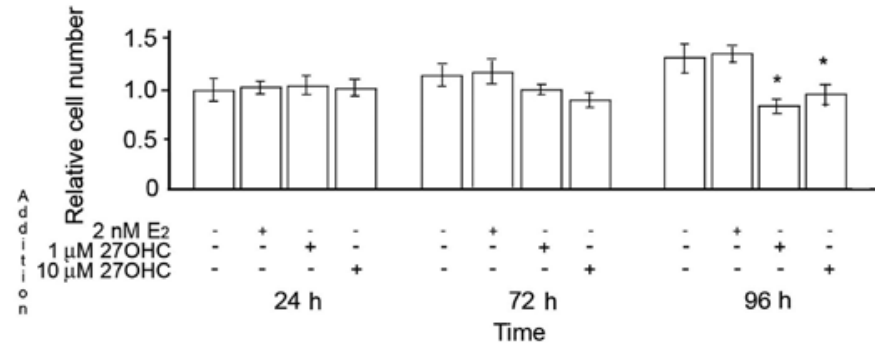

Figure 2. Proliferation of MCF10 cells cultured in the absence or presence of $2 \mathrm{nM}$ estradiol or of two concentrations of $27 \mathrm{OHC}$. The proliferation of MCF10 cells exposed or not to either estradiol or $27 \mathrm{OHC}$ is shown. The proliferation rate was expressed as the relative cell number calculated in relation to the number of control cells at $24 \mathrm{~h}$ after seeding, which was set to 1 . Values are the mean \pm SD of 3 experiments performed in triplicate. Non-significant differences relative to the control cells were noted for cells exposed to $2 \mathrm{nM} \mathrm{E}_{2} .{ }^{\text {*Significant }}$ difference $(\mathrm{P}<0.05)$ relative to the non-stimulated control cells at $96 \mathrm{~h}$.

stimulatory effect was obtained with $1-2 \mu \mathrm{M} 27 \mathrm{OHC}$, and was in the same order of magnitude as that obtained with $2 \mathrm{nM} \mathrm{E}_{2}$. Similar effects of $\mathrm{E}_{2}$ and $27 \mathrm{OHC}$, albeit with slower proliferation rates, were observed in ER-positive ZR75 cells (data not shown).

In contrast to MCF7 and ZR75 cells, when MCF10 cells were incubated under the same conditions, neither estradiol nor $27 \mathrm{OHC}$ had an effect on cell proliferation during the first $24 \mathrm{~h}$. Later during the exposure, $2 \mathrm{nM} \mathrm{E_{2 }}$ still exhibited no effects, while 1-10 $\mu \mathrm{M} 27 \mathrm{OHC}$ induced a reduction in the number of MCF10 cells in comparison to non-treated cells (Fig. 2).

The effects of $27 \mathrm{OHC}$ and estradiol on the proliferation of MCF7 cells, compared using BrdU pulses to stain proliferating cells in the S-phase of the cell cycle, were completely abolished by $100 \mathrm{nM} \mathrm{ICI}$, as shown in Fig. 3 .

Fig. 4 depicts a representative cycle analysis of cells stimulated for $48 \mathrm{~h}$ with $2 \mathrm{nM} \mathrm{E}_{2}$ or with 1-2 $\mu \mathrm{M} 27 \mathrm{OHC}$, and the respective effects of $100 \mathrm{nM}$ ICI. Stimulation with $\mathrm{E}_{2}$ or $27 \mathrm{OHC}$ brought a similar number of cells into the S-phase. These effects were completely abolished by ICI. The analyses

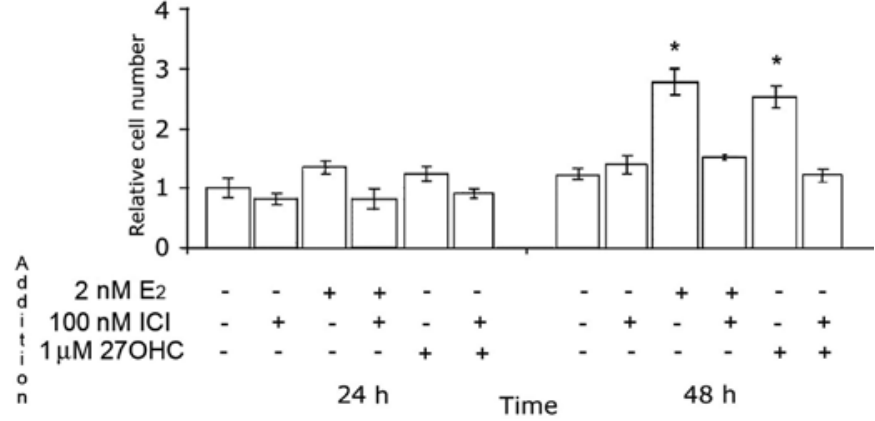

Figure 3. Effect of ICI 182,780 (ICI) on the proliferation in culture of MCF7 cells exposed or not to $\mathrm{E}_{2}$ or $27 \mathrm{OHC}$. The proliferation of non-exposed cells or of cells exposed to $100 \mathrm{nM} \mathrm{ICI}, 2 \mathrm{nM} \mathrm{E}_{2}$ alone; $2 \mathrm{nM} \mathrm{E}_{2}$ and $100 \mathrm{nM}$ ICI, $1 \mu \mathrm{M} 27 \mathrm{OHC}$ alone, or $1 \mu \mathrm{M} 27 \mathrm{OHC}$ and $100 \mathrm{nM}$ ICI, is depicted. The proliferation rate was expressed as the relative cell number calculated in relation to the number of control cells at $24 \mathrm{~h}$ after seeding, which was set to 1 . Values are the mean $\pm \mathrm{SD}$ of 3 experiments performed in triplicate. ${ }^{*} \mathrm{P}<0.05$ at $48 \mathrm{~h}$ for differences between $\mathrm{E}_{2}$ vs. $\mathrm{E}_{2}+\mathrm{ICI}$ and $27 \mathrm{OHC}$ vs. $27 \mathrm{OHC}+\mathrm{ICI}$. Differences between the other pairs were non-significant.

also indicated that the extent of apoptosis was not significantly altered within the tested exposure duration. After $24 \mathrm{~h}$ of stimulus, $\mathrm{E}_{2}$ and the novel SERM significantly increased the percentage of cells in the S-phase. In this case, the effects were completely abolished by $100 \mathrm{nM} \mathrm{ICI}$ (data not shown).

As depicted in Fig. 5, the effect of $27 \mathrm{OHC}$ was completely abolished by simvastatin. The maximal effect of this HMGR inhibitor was obtained at $1 \mu \mathrm{M}$; notably, the proliferation of MCF7 cells under estradiol stimulation was not affected by the addition of simvastatin at this concentration. Also of note, $2 \mu \mathrm{g} / \mathrm{ml}$ AFPep inhibited the proliferation of MCF7 cells stimulated with $2 \mathrm{nM} \mathrm{E}_{2}$, but did not affect the influence of $27 \mathrm{OHC}$ on cell growth.

As compared to control non-stimulated MCF7 cells, EGFR2 immunoreactivity increased after a 15-min stimulation with $2 \mathrm{nM} \mathrm{E}_{2}$. This effect was abolished by $2 \mu \mathrm{g} / \mathrm{ml}$ AFPep. No effects on EGFR 2 reactivity were observed upon exposure to $1 \mu \mathrm{M} 27 \mathrm{OHC}$, independent of the presence of AFPep or
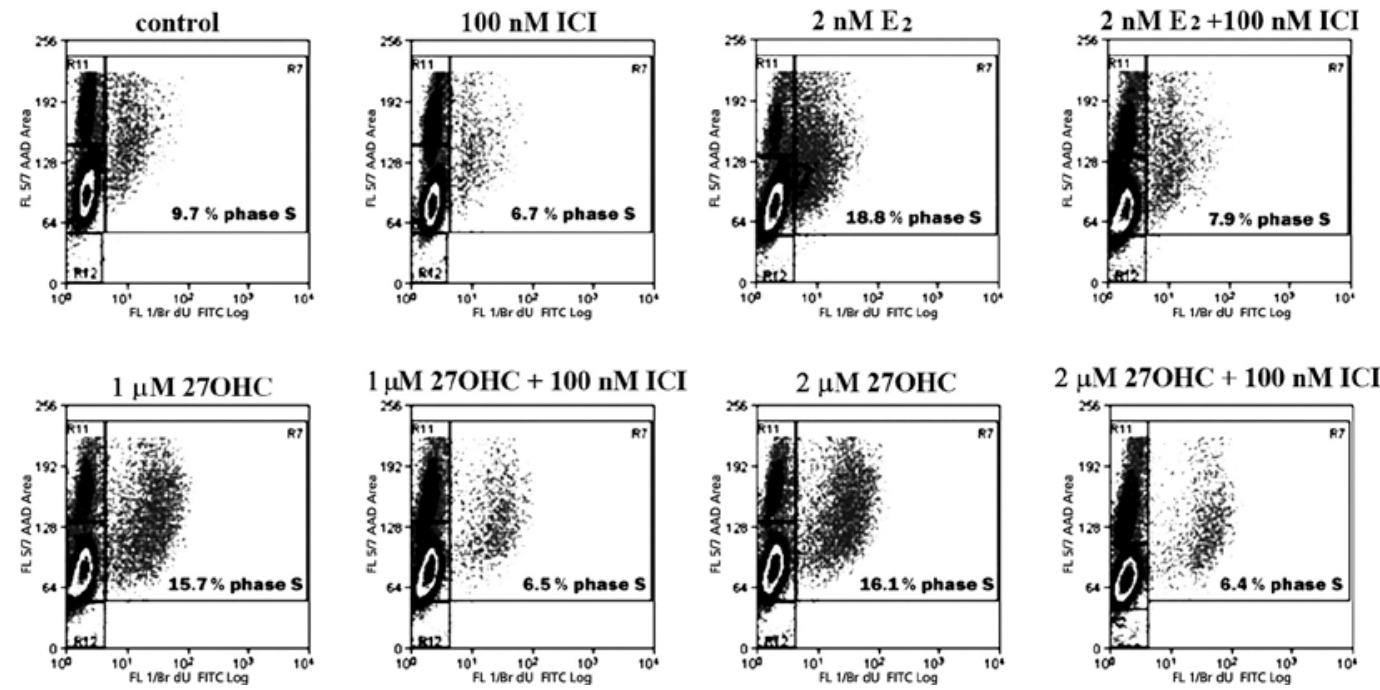

Figure 4. Cell cycle analysis of MCF7 after stimulation with $\mathrm{E}_{2}$ or $27 \mathrm{OHC}$. The panels depict representative dot-plots. Labels indicate the percentage of cells found at the S-phase after a 48-h long exposure to vehicle or to $2 \mathrm{nM} \mathrm{E}_{2}, 1 \mu \mathrm{M} 27 \mathrm{OHC}$ or $2 \mu \mathrm{M} 27 \mathrm{OHC}$, in the absence or presence of $100 \mathrm{nM}$ ICI. 


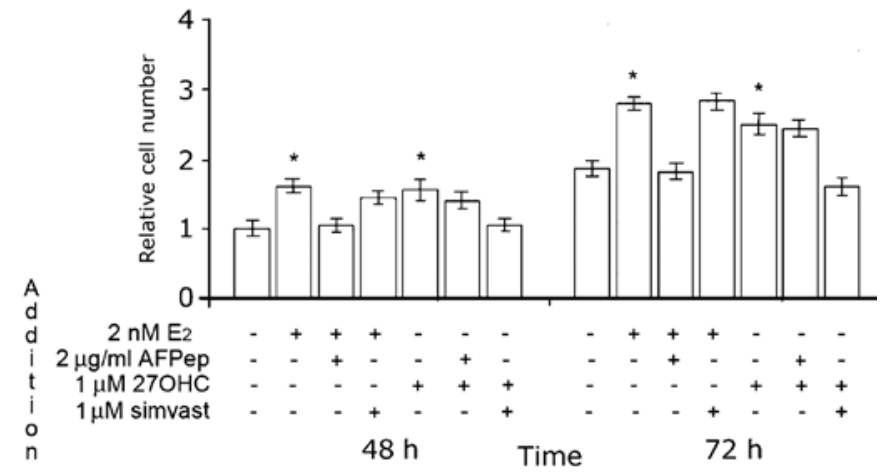

Figure 5. Differential effects of AFPep and simvastatin on the proliferation of unstimulated and stimulated MCF7 cells in culture. The proliferation of non-stimulated MCF7 cells or of cells exposed to $2 \mathrm{nM} \mathrm{E}_{2}$ or to $1 \mu \mathrm{M} 27 \mathrm{OHC}$ in the absence or presence of either $2 \mu \mathrm{g} / \mathrm{ml}$ AFPep or $1 \mu \mathrm{M}$ simvastatin, is depicted. The proliferation rate was expressed as the relative cell number calculated in relation to the number of control cells at $24 \mathrm{~h}$ after seeding, which was set to 1 . Values are the mean $\pm \mathrm{SD}$ of 3 experiments performed in triplicate. ${ }^{*} \mathrm{P}<0.05$ at 48 and $72 \mathrm{~h}$ for differences between AFPep $+\mathrm{E}_{2}$ vs. $\mathrm{E}_{2}$ and $27 \mathrm{OHC}+$ simvastatin vs. $27 \mathrm{OHC}$.

Table I. Comparative effects of $27 \mathrm{OHC}$ and cholesterol on the proliferation of MCF7 cells.

\begin{tabular}{lcc}
\hline Treatment & \multicolumn{2}{c}{ Proliferation } \\
\cline { 2 - 3 } & $48 \mathrm{~h}$ & $72 \mathrm{~h}$ \\
\hline Control & $1.00 \pm 0.06$ & $1.51 \pm 0.05$ \\
$1 \mu \mathrm{M} 27 \mathrm{OHC}$ & $1.78 \pm 0.07^{\mathrm{a}}$ & $2.63 \pm 0.07^{\mathrm{a}}$ \\
$1 \mu \mathrm{M} 27 \mathrm{OHC}+1 \mu \mathrm{M}$ simvastatin & $1.04 \pm 0.08$ & $1.33 \pm 0.09$ \\
$5 \mu \mathrm{M}$ cholesterol & $1.03 \pm 0.05$ & $1.56 \pm 0.09$ \\
$5 \mu \mathrm{M}$ cholesterol $+1 \mu \mathrm{M}$ simvastatin & $0.96 \pm 0.05$ & $1.36 \pm 0.09$ \\
$20 \mu \mathrm{M}$ cholesterol & $1.10 \pm 0.03$ & $1.61 \pm 0.02$ \\
$20 \mu \mathrm{M}$ cholesterol $+1 \mu \mathrm{M}$ simvastatin & $1.06 \pm 0.12$ & $1.66 \pm 0.09$ \\
\end{tabular}

MCF7 cells $\left(15,000 / \mathrm{cm}^{2}\right)$ were seeded on P24 plates and incubated for $24 \mathrm{~h}$ in medium containing $10 \%$ fetal bovine serum. The attached cells were incubated for $24 \mathrm{~h}$ with medium containing $1 \%$ charcoal-treated serum, 3\% HAES and ITS, and then exposed for the indicated times to either $27 \mathrm{OHC}$ or cholesterol in The proliferation rate was expressed as the relative cell number calculated in relation to the number of control cells at $48 \mathrm{~h}$ after seeding, which was set to 1 . Values are the mean $\pm \mathrm{SD}$ of 3 experiments performed in triplicate. The medium was either used directly as the control or adjusted to $1 \mu \mathrm{M} 27 \mathrm{OHC}$ or 5 or $20 \mu \mathrm{M}$ cholesterol in the absence or presence of $1 \mu \mathrm{M}$ simvastatin. ${ }^{\text {a }} \mathrm{P}<0.05$ at 48 or $72 \mathrm{~h}$ for differences between the control vs. $1 \mu \mathrm{M} 27 \mathrm{OHC}$.

simvastatin. Fig. 6 depicts representative fluorescence images of these experiments.

Unlike 27OHC, cholesterol added at concentrations of up to $20 \mu \mathrm{M}$ did not show any stimulatory effect on MCF7 cell proliferation, as summarized in Table I.

\section{Discussion}

Cholesterol is abundantly distributed in eukaryotes. In higher animals, the main sources of circulating cholesterol are the uptake from fat rich foods and endogenous synthesis (12).

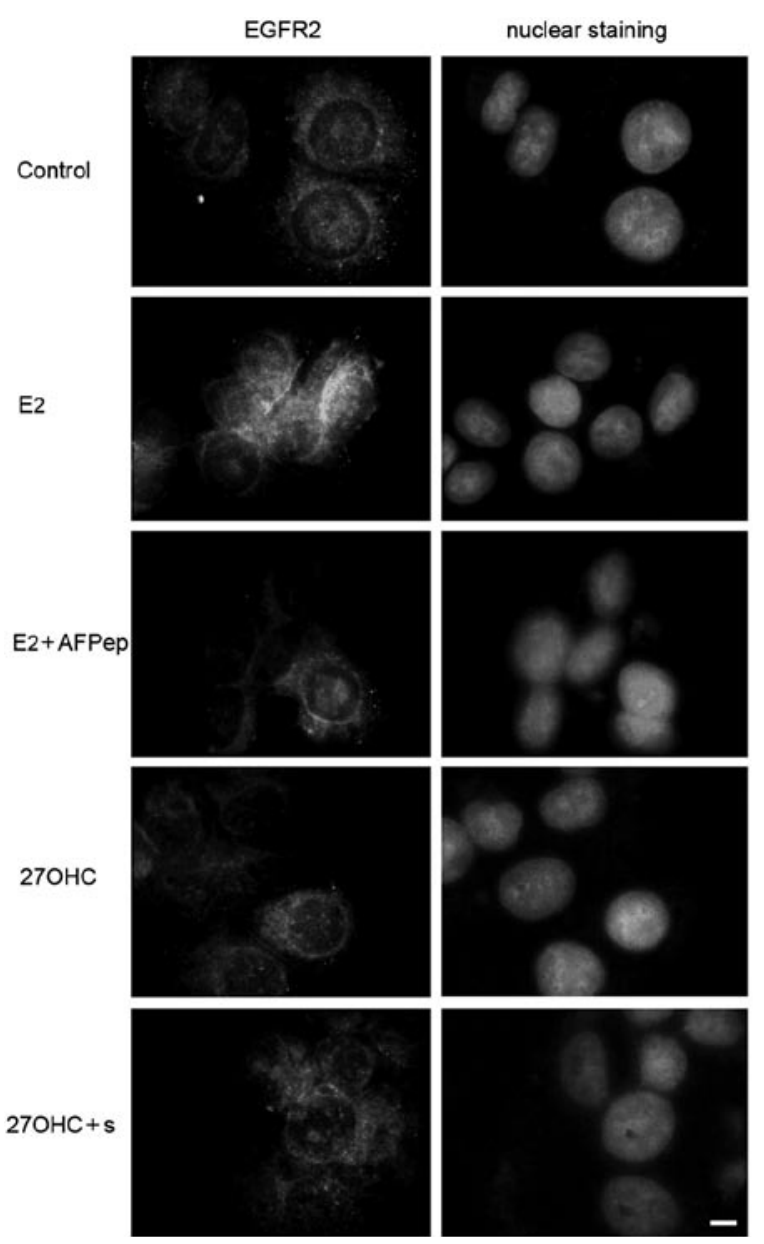

Figure 6. Immunofluorescence analysis of EGFR2 in MCF7 cells exposed to estradiol or 27OHC. Representative fluorescence images of EGFR2 in MCF7 cells grown for $48 \mathrm{~h}$ in medium containing $1 \%$ charcoal-treated serum and $3 \%$ HAES, then stimulated for 15 min with $2 \mathrm{nM} \mathrm{E}_{2}$ alone, $2 \mathrm{nM} \mathrm{E}_{2}+2 \mu \mathrm{g} /$ $\mathrm{ml}$ AFPep, $1 \mu \mathrm{M} 27 \mathrm{OHC}$ alone or $1 \mu \mathrm{M} 27 \mathrm{OHC}+1 \mu \mathrm{M}$ simvastatin (s), or maintained in medium alone (control). Images on the left depict EGFR2immunofluorescence; images on the right depict nuclear staining of the respective cells. Scale bar, $20 \mu \mathrm{m}$.

The blood of normal human subjects contains several oxidized metabolites of cholesterol (oxysterols). Of these, $27 \mathrm{OHC}$ is the most abundant species, reflecting cholesterol saturation in the body and predicting to some extent the responsiveness to dietary cholesterol (13). Circulating 27OHC levels increase in cardiovascular disease (14), and this metabolite is easily detected in macrophages isolated from atherosclerotic lesions (15). Due to their higher polarity and limited stuffing in cell membranes, oxysterols share the ability to translocate faster than cholesterol across membranes, allowing their participation in cell signaling, lipid metabolism and vesicle transport (16). $27 \mathrm{OHC}$ affects some cellular functions in macrophages (17); in fact, the oxysterol exhibits a concentration-dependent regulation in human macrophages: low concentrations of $27 \mathrm{OHC}$, favor cell survival, while high concentrations induce apoptosis (18). Some authors have reported that, in macrophages and in certain intestinal cancer human cell lines, $27 \mathrm{OHC}$ activates the liver orphan receptor $\alpha(\mathrm{LXR} \alpha)$, inducing the expression of efflux transporters ABCA1 and ABCG1 and thus promoting the detoxification of cholesterol metabolites (19). Many other cells are affected by $27 \mathrm{OHC}$, including 
vascular smooth muscle cells (20) and endothelial cells (21). Certain effects of $27 \mathrm{OHC}$ are probably a consequence of its potent HMGR inhibitory activity (22).

In the present study, we compared the effects of $27 \mathrm{OHC}$ and estradiol on the proliferation of mammary tumor cells in culture. The results confirmed earlier evidence regarding a mitogenic activity of $27 \mathrm{OHC}$ in estrogen-responsive breast tumor cells. Similarly to estradiol, $1 \mu \mathrm{M} 27 \mathrm{OHC}$ was found to stimulate the proliferation of MCF7 cells, promoting significant changes in the fraction of cells entering the DNA-synthesis phase in the cell-cycle. The effects of $27 \mathrm{OHC}$ and estradiol on MCF7 cells were counteracted to the same extent by the pure estrogen-antagonist ICI 182,780. Neither estradiol nor $27 \mathrm{OHC}$ or ICI affected the proliferation of non-tumorigenic MCF10 cells. The stimulatory effect of $27 \mathrm{OHC}$ differed from that from $\mathrm{E}_{2}$ in relation to the sensitivity to $1 \mu \mathrm{M}$ simvastatin and to AFPep, respectively. In the first case, obtained at the optimal concentrations of $27 \mathrm{OHC}$ and simvastatin, the results suggest that these HMGR inhibitors may act additively, most probably causing a decrease in the isoprenylation capacity. At the same concentration of simvastatin, no major changes were observed in estradiol-induced MCF7 proliferation, probably because isoprenylation was not dramatically affected (Sierralta et al, unpublished data).

In ER-positive human and canine mammary tumor cells, AFPep is an effective inhibitor of estradiol-stimulated proliferation $(23,24)$. This cyclized nonapeptide disturbs membrane receptor-tyrosine kinase signaling pathways regulated by growth factors $(25,26)$. By indirect immunofluorescence, we detected an increase in EGFR2 reactivity after $2 \mathrm{nM}$ estradiol. This was abolished by AFPep; however, upon exposure to $1 \mu \mathrm{M} 27 \mathrm{OHC}$, no changes in EGFR2 immunoreactivity were detected, suggesting that estradiol and $27 \mathrm{OHC}$ have different mechanisms of action.

$27 \mathrm{OHC}$ is a low-affinity ER ligand, and there remain some doubts regarding its actual physiological relevance. As pointed out by DuSell and McDonnell (27), during estrogendepletion, 27OHC affects ER by acting as a type of intracrine/ paracrine modulator, and not as a classical endocrine agent. In mammary cancer cells, $27 \mathrm{OHC}$ works as a partial ER agonist that recruits ER $\alpha$ to target gene promoters and controls the transcription of ER target genes (11). The ability of $27 \mathrm{OHC}$ to stimulate, at physiological concentrations, the proliferation of ER $\alpha$-positive mammary-cancer cells would appear to be of major physiological importance.

Occasionally, resistance develops during the treatment of breast cancer with anti-estrogens and aromatase inhibitors. Many therapy-resistant breast cancers do maintain ER expression, indicating the continued operation of estrogen signaling pathways. A permanently activated ER may well be the consequence of an association with endogenously produced SERMs, such as $27 \mathrm{OHC}$. Through the metabolism of profusely available plasma membrane cholesterol, many cells produce and secrete $27 \mathrm{OHC}$ in their neighborhood, as demonstrated in the case of fibroblasts (28). The infiltration of macrophages is an indicator of poor prognosis in patients with a mammary gland affected by a tumor (29). It has been demonstrated that macrophages actively increase the local formation of $27 \mathrm{OHC}$ (30). Taken together, these findings suggest that, in tissues infiltrated by cancer, a constant stimu- lation of tumor cells may be caused by the activity of local macrophages. It was previously thought that the increased risk of breast cancer caused by obesity was mainly due to enhanced aromatase capacity in adipose tissue, which generates higher local concentrations of estradiol. Since obesity is associated with hypercholesterolemia and increased $27 \mathrm{OHC}$ production, a proliferative effect of this oxysterol on ER-positive cancer cells is likely to be more intense in obese patients.

Besides binding to $\mathrm{ER}, 27 \mathrm{OHC}$ is considered a potential ligand of orphan receptor LXR (31). This interaction should be taken into consideration, since Vedin et al (32) have reported the growth-inhibitory effects of LXR agonist GW3965 in ER-positive breast cancer cell lines. This anti-proliferative effect was absent in ER-negative cell lines, suggesting that ER plays an important mediator role in the process (32).

A complete understanding of whether the final cell response depends on the proportions of ER and LXR and the ratios of SERM and SLXRM present at a given time in a particular tissue requires further study. In the meantime, there is agreement that an ample characterization of all the mechanisms involved in estrogen-stimulated breast cancer growth is required to improve diagnosis and the ability to predict the response of a tumor to a specified therapy (33). As would be expected due to the complexity of any biological system, it is safe to predict that many more as yet unknown interacting factors are involved in the modulation of cancer cell growth.

\section{Acknowledgements}

We are grateful to Professors H.I. Jacobson, J. Bennett and T.T. Andersen (Albany Medical College, NY, USA) for providing the AFPep. This study was supported by Fondecyt Chile, Grant 1090057.

\section{References}

1. Russo IH and Russo J: Role of hormones in mammary cancer initiation and progression. J Mammary Gland Biol Neoplasia 3: 49-61, 1998.

2. Conzen SD: Nuclear receptors and breast cancer. Mol Endocrinol 22: 2215-2228, 2008.

3. Fox EM, Andrade J and Shupnik MA: Novel actions of estrogen to promote proliferation integration of cytoplasmic and nuclear pathways. Steroids 74: 622-627, 2009.

4. Madak-Erdogan Z, Kieser KJ, Kim SH, Komm B, Katzenellenbogen JA and Katzenellenbogen BS: Nuclear and extranuclear pathway inputs in the regulation of global gene expression by estrogen receptors. Mol Endocrinol 22: 2116-2127, 2008.

5. He J, Cheng Q and Xie W: Minireview: nuclear receptorcontrolled steroid hormone synthesis and metabolism. Mol Endocrinol 24: 11-21, 2010.

6. Sasano H, Suzuki T, Nakata T and Moriya T: New development in intracrinology of breast carcinoma. Breast Cancer 13: 129-136, 2006.

7. Arpino G, Weichmann L, Osborne CK and Schiff R: Crosstalk between the estrogen receptor and the HER tyrosine kinase receptor family: molecular mechanism and clinical implications for endocrine therapy resistance. Endocr Rev 29: 217-233, 2008.

8. Hall JM and McDonnell DP: Coregulators in nuclear estrogen receptor action: from concept to therapeutic targeting. Mol Interv 5: 343-357, 2005.

9. Shelly W, Draper MW, Krishnan V, Wong M and Jaffe RB: Selective estrogen receptor modulators: an update on recent clinical findings. Obstet Gynecol Surv 63: 163-181, 2008. 
10. Umetani M, Domoto H, Gormley AK, Yuhanna IS, Cummins CL, Javitt NB, Korach KS, Shaul PW and Mangelsdorf DJ: 27-Hydroxycholesterol is an endogenous SERM that inhibits the cardiovascular effects of estrogens. Nature Med 13: 1185-1192, 2007.

11. DuSell CD, Umetani M, Shaul PW, Mangelsdorf DJ and McDonnell DP: 27-Hydroxycholesterol is an endogenous selective estrogen receptor modulator. Mol Endocrinol 22: 65-77, 2008

12. Brown AJ and Jessup W: Oxysterols and atherosclerosis. Atherosclerosis 142: 1-28, 1999.

13. Hirayama T, Mizokami Y, Honda A, Homma Y, Ikegami T, Saito Y, Miyazaki T and Matsuzaki Y: Serum concentration of 27-hydroxycholesterol predicts the effects of high-cholesterol diet on plasma LDL cholesterol level. Hepatol Res 39: 149-156, 2009.

14. Babiker A, Dzeletovic S, Wiklund B, Pettersson N, Salonen J, Nyyssönen K, Eriksson M, Diczfalusy U and Björkhem I: Patients with atherosclerosis may have increased circulating levels of 27-hydroxycholesterol and cholestenoic acid. Scand J Clin Lab Invest 65: 365-375, 2005.

15. Hultén LM, Lindmark H, Diczfalusy U, Björkhem I, Ottosson M, Liu Y, Bondjers G and Wiklund O: Oxysterols present in atherosclerotic tissue decrease the expression of lipoprotein lipase messenger RNA in human monocyte-derived macrophages. J Clin Invest 97: 461-468, 1996.

16. Olkkonen VM and Hynynen R: Interactions of oxysterols with membranes and proteins. Mol Aspects Med 30: 123-133, 2009.

17. Lemaire-Ewing S, Prunet C, Montange T, Vejux A, Berthier A, Bessede G, Corcos L, Gambert P, Neel D and Lizard G: Comparison of the cytotoxic, pro-oxidant and pro-inflammatory characteristics of different oxysterols. Cell Biol Toxicol 21: 97-114, 2005.

18. Riendeau V and Garenc C: Effect of 27-hydroxycholesterol on survival and death of human macrophages and vascular smooth muscle cells. Free Radic Res 43: 1019-1028, 2009.

19. Li T, Chen W and Chiang JY: PXR induces CYP27A1 and regulates cholesterol metabolism in the intestine. J Lipid Res 48: 373-384, 2007.

20. Oyama T, Miyashita Y, Kinoshita K, Watanabe H, Shirai K and Yagima T: Effect of deposited lipids in atheromatous lesions on the migration of vascular smooth muscle cells. J Atheroscler Thromb 9: 109-113, 2002.

21. Kummerow FA, Mahfouz MM, Zhou Q and Cook LS 27-Hydroxycholesterol causes remodeling in endothelial cell membrane lipid composition comparable to remodeling in the failed vein grafts of CABG patients. Life Sci 78: 958-963, 2006.
22. Lange Y, Ory DS, Ye J, Lanier MH, Hsu FF and Steck TL: Effectors of rapid homeostatic responses of endoplasmic reticulum cholesterol and 3-hydroxy-3-methylglutaryl-CoA reductase. J Biol Chem 283: 1445-1455, 2008.

23. Sierralta WD, Epuñán MJ, Reyes JM, Valladares LE, Andersen TT, Bennett JA, Jacobson HI and Pino AM: A peptide derived from $\alpha$-fetoprotein inhibits the proliferation induced by estradiol in mammary tumor cells in culture. Oncol Rep 19: 229-235, 2008

24. Sierralta WD, Epuñán MJ, Reyes JM, Valladares LE and Pino AM: A cyclic nonapeptide derived from alpha-fetoprotein inhibits the estradiol-induced proliferation of mammary tumor cells in culture through the modulation of p21. Adv Exp Med Biol 617: 463-468, 2008

25. Torres C, Antileo E, Epuñán MJ, Pino AM, Valladares LE and Sierralta WD: A cyclic peptide derived from $\alpha$-fetoprotein inhibits the proliferative effects of the epidermal growth factor and estradiol in MCF7 cells. Oncol Rep 19: 1597-1603, 2008.

26. Torres CG, Pino AM and Sierralta WD: A cyclized peptide derived from $\alpha$-fetoprotein inhibits the proliferation of ER-positive canine mammary cancer cells. Oncol Rep 21: 1397-1404, 2009

27. DuSell CD and McDonnell DP: 27-Hydroxycholesterol: a potential endogenous regulator of estrogen receptor signaling. Trends Pharmacol Sci 29: 510-514, 2008.

28. Lange Y, Steck TL, Ye J, Lanier MH, Molugu V and Ory D: Regulation of fibroblast mitochondrial 27-hydroxycholesterol production by active plasma membrane cholesterol. J Lipid Res 50: 1881-1888, 2009.

29. Steele RJ, Eremin O, Brown M and Hawkins RA: A high macrophage content in human breast cancer is not associated with favourable prognostic factors. Br J Surg 71: 456-458, 1984.

30. Javitt NB: 25R,26-Hydroxycholesterol revisited: synthesis, metabolism and biologic roles. J Lipid Res 43: 665-670, 2002.

31. Chen W, Chen G, Head DL, Mangelsdorf DJ and Russell DW: Enzymatic reduction of oxysterols impairs LXR signaling in cultured cells and the livers of mice. Cell Metab 5: 73-79, 2007.

32. Vedin LL, Lewandowski SA, Parini P, Gustafsson JA and Steffensen KR: The oxysterol receptor LXR inhibits proliferation of human breast cancer cells. Carcinogenesis 30: 575-579, 2009.

33. Culhane AC and Howlin J: Molecular profiling of breast cancer: transcriptomic studies and beyond. Cell Mol Life Sci 64: 3185-3200, 2007. 